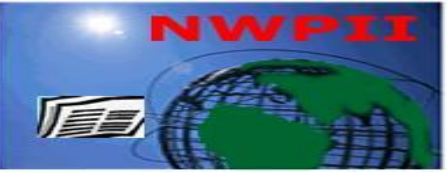

\title{
Pattern and Sero-prevalence of Covid-19 Screening among Patients in a Tertiary Hospital, South-western Nigeria
}

\author{
Abiodun K. Ajeigbe*, Tewogbade A. Adedeji, Olabamiji A. Ajose, Olusola A. Jeje, Olufemi S. Smith, \\ Medinat B. Bello, Oluwabori E. Olukoyejo, Olawale J. Jokanola, Ronke A. Makinde, Ifeoluwa H. \\ Ojelabi, Olufunke O. Odun-Afolabi, Ogra V. Ogra.
}

Department of Chemical Pathology, Obafemi Awolowo University Teaching Hospitals Complex, Ile-Ife.

"Corresponding Author

Abiodun Kofoworola Ajeigbe

Department of Chemical Pathology

Obafemi Awolowo University, Ile-Ife

Nigeria

Tel:+234803690269

Email:abiodunalaje1@gmail.com

Received:20 August 2021; | Revised:24 September 2021; | Accepted:08 December 2021

Background: The global pandemic due to the severe acute respiratory syndrome coronavirus 2 (SARSCoV-2) and its related COVID-19 infection has placed more demand and responsibility on clinical laboratories for screening and confirmatory tests. The serological tests for screening appear to be of great benefit in resource poor settings like ours to facilitate diagnosis and monitoring of COVID-19 infection. We therefore, determined the pattern and the sero-prevalence of SARSCoV-2 based on requests received at the Point of Care Testing Unit of the OAUTHC, Ile-Ife.

Methods: A total of 1653 results of SARS-CoV-2 serology requests were assessed in this descriptive study. All requests received within a period of six months were analyzed for age, gender, sources and immunoglobulin pattern for sero-prevalence using descriptive statistics. Requests were categorized into pediatric and adult age groups, while results were compared between male and female gender.

Results: Requests from children and adults accounted for 284 and 1369 respectively in a male to female ratio of 1.07:1 in children and 1:1.07 in adults. There was a bimodal mean age of 8.6 \pm 0.35 years and $34.2 \pm 0.7$ years in children and adults respectively. The highest requests were from surgery and emergency units accounting for $28 \%$ and $26 \%$ respectively. Adult females had a higher IgG sero-prevalence while adult males reacted more to IgM. Overall sero-prevalence of SARS-CoV-2 was $26.3 \%$ giving $20 \%$ and $27 \%$ for children and adults respectively.

Conclusion: The sero-prevalence of SARSCoV-2 was higher among adult population and female gender appeared to be a modifying factor.

Keywords: COVID-19, Serology, Screening 


\section{Background}

Up to now, there's no solid evidence to prove that an outbreak of acute respiratory disease reported in December 2019 was from Wuhan district of Huben Province of China. The aetiology of the disease was unknown until its genome was identified and deposited on GenBank (MN908947) by Zhang et al ${ }^{[1]}$. This 2019 novel Coronavirus (2019-nCoV) was renamed by the Coronavirus Study Group of the International Committee on Taxonomy of Viruses (ICTV) as severe acute respiratory syndrome coronavirus 2 (SARS-Cov-2) [2]. Although, the novel $\mathrm{CoV}$ was first reported in China, it has spread globally with high mortality and morbidity rates. In April 2020, it was reported that the total number of confirmed cases in Nigeria was 873 with 28 deaths while the global figure was $1,978,769$ with 125,196 mortality. The values had increased by June 30, 2020 with confirmed cases above 10 million and more than 500 deaths globally [3-4].

In Nigeria, a low-medium income country (LMIC) with grossly mismanaged health resources and poor health indices, the first case of COVID-19 infection was reported on 27th of February. Due to increasing spread of the virus, 25,694 cases and 590 deaths were recorded by mid-2020 ${ }^{[5-6]}$. The disease is observed to be more common among males ${ }^{[7-9]}$, while mortality is higher in elderly patients with comorbidities and frontline health workers [10]. However, prevalence appears lower in children ${ }^{[8,11-}$ ${ }^{12]}$. Respiratory symptoms remain the predominant form of presentation following a 2-week incubation period. Although, some infected patients may be asymptomatic, symptoms like fever, cough and respiratory difficulty were found in $95 \%, 50 \%$ and $33 \%$ of symptomatic cases respectively ${ }^{[13-14]}$.

Due to the high spread of the virus, the need for mass screening has placed more demand on clinical laboratories to facilitate diagnosis and monitoring. Most countries have also mandated screening as part of travel regulations. SARS-CoV2 being a rapidly spreading viral infection necessitates diverse heterogeneous approaches to its diagnosis. The gold standard for the diagnosis of COVID-19 recommended by WHO, is the molecular technique approach using the real time polymerase chain reaction (RT-PCR) to identify the viral genes $\mathrm{E}, \mathrm{RdRp}$ and $\mathrm{N}^{[15-16]}$. In the United States of America, a combination of viral N1/2/3 gene and $\mathrm{P}$ gene is widely in use ${ }^{[15]}$. However, due to limited molecular laboratory facilities to screen a large population like that of Nigeria, other approaches employed were the use of rapid diagnostic testing (RDT) kits to detect the combination of $\mathrm{IgG} / \mathrm{M}$ antibodies by immunoasay or by targeting the viral E gene for screening, with only a positive test necessitating confirmation by RT-PCR. Previous studies reported a high sensitivity (87.3-88.7\%) and even higher specificity (90.6-98.6\%) for both IgM and IgG to emphasize the analytic and diagnostic utility of the RDT kits ${ }^{[17-18]}$. Based on this, we assessed the serology pattern of requests for SARSCoV-2 and determined the sero-prevalence of positive SARSCoV-2 results.

\section{Methods}

This was a descriptive analytical study involving a total of 1653 requests for SARS-CoV 19 antibody screening tests at the Postgraduate Laboratory of the Department of Chemical Pathology, Obafemi Awolowo University Teaching Hospitals Complex (OAUTHC), Ile-Ife. The period of assessment was between May and December, 2020. The SARS CoV-2 antibody reagent test kits were purchased from CTK biotechnology Inc., 13855 Stowe Drive Poway, California 92064, USA with reference SB-RO180C, Lot numbers SO11428-204 and FO417R8BO2V. The assay method is based on lateral flow immunoassay technique for qualitative detection of SARS-CoV-2 $\operatorname{IgG}$ and $\operatorname{IgM}$ antibodies in serum.

The request forms were screened assessed for the information on sources such as private or public health care facility, clinic or ward, demography, background clinical details while the results of the antibody screening were analyzed to determine the immunoglobulin types found in the positive results. Data was analyzed by Statistical Package for Scientific Solutions (SPSS) version 20 (IBM, USA) using descriptive statistics.

\section{Results}

There was a bimodal mean age of $34.2 \pm 0.7$ and $8.6 \pm 0.35$ and a male to female ratio of $1: 1.07$ 
and 1.07:1 for adults and children respectively (table 1). There was a slight female preponderance (50.9\%) for requests when compared with requests from males $(47.2 \%)$. The requests received were mainly from patients attending the OAUTHC within the period of assessment and accounted for $93.5 \%$ while $6.5 \%$ requests were from private facilities. The Department of Surgery contributed highest to SARSCoV-2 serology requests followed by the Emergency and the Pediatrics Departments accounting for $28 \%, 26 \%$ and $14 \%$ respectively. Surprisingly, the General Out-Patient Department (GOPD) had the least number of requests (table 2).

The results of SARS-CoV-2 screening showed 432 positive cases reflecting a sero-prevalence of
$26.3 \%$. Requests from the emergency room had the highest sero-positive rates 135 (31.3\%) when compared to other sources. Total IgM seropositivity was higher (318) than the total IgG (290) sero-positivity. Both IgM and IgG antibodies were positive in 174 , while isolated $\operatorname{IgM}$ or $\operatorname{IgG}$ were positive for 143 and 115 requests respectively (table $3)$. However, children had a higher sero-positive IgG $(18.0 \%)$ than IgM (15.1\%) while IgM seropositivity remained higher in adults than in children (19.4\% vs $17.3 \%$ ) irrespective of sex (table 4 ).

Females had a higher sero-positive rate $51.9 \%$ (230) than males in both children and adults except for IgM which was higher in adult males (table 4).

Table 1: Demography, Sources of Requests and Status of SARSCoV-2 Serology

\begin{tabular}{|c|c|c|c|c|}
\hline SARS-CoV 2 & \multicolumn{3}{|c|}{ Request } & \\
\hline & $\mathrm{n}=1369(82.8)$ & $\mathrm{n}=284(17.2)$ & $\mathrm{n}=1653(100)$ & \\
\hline Mean Age (years) & $34.2 \pm 0.7$ & $8.6 \pm 0.35$ & & \\
\hline $\operatorname{Sex}$ & Frequency $(\%)$ & Frequency $(\%)$ & & \\
\hline Male & $653(47.7)$ & $145(51.1)$ & & \\
\hline Female & $716(52.3)$ & $139(48.9)$ & & \\
\hline Total & $1369(100)$ & $284(100)$ & & \\
\hline \multicolumn{5}{|c|}{ SOURCES OF SARS-CoV 2 REQUESTS } \\
\hline Department & Frequency $(\%)$ & $\begin{array}{l}\text { SARSCoV } 2 \text { Positive } \\
(\%)\end{array}$ & $\begin{array}{l}\text { Total IgG Positive } \\
(\%)\end{array}$ & $\begin{array}{l}\text { Total IgM Positive } \\
(\%)\end{array}$ \\
\hline Emergency & $442(26.7)$ & $135(8.17)$ & $89(5.38)$ & $98(5.93)$ \\
\hline Surgery & $481(29.0)$ & $128(7.74)$ & $94(5.69)$ & $93(5.63)$ \\
\hline Pediatrics & $234(14.2)$ & $45(2.72)$ & $33(2.0)$ & $31(1.88)$ \\
\hline$*$ Other & $221(13.4)$ & $62(3.75)$ & $40(2.42)$ & $43(2.60)$ \\
\hline GOPD & $49(3.0)$ & $06(0.36)$ & $04(0.24)$ & $05(0.30)$ \\
\hline Private Hospital & $107(6.5)$ & $23(1.39)$ & $12(0.73)$ & $18(1.09)$ \\
\hline Medicine & $119(7.2)$ & 33 (1.99) & 18 (1.09) & $30(1.81)$ \\
\hline Total & $1653(100)$ & $432(26.1)$ & $290(17.55)$ & $318(19.24)$ \\
\hline
\end{tabular}

*Opthalmology, Obstetrics and Gynaecology, Ear/Nose and Throat

Table 2: Assessment of SARS-CoV 2 IgM and IgG Positive Results

\begin{tabular}{lllll}
\hline Source & Isolated IgM & Isolated IgG & Combined IgM/G & Total IgM/G \\
& F $(\boldsymbol{\%})$ & F $(\boldsymbol{\%})$ & $\mathbf{F}(\boldsymbol{\%})$ & F $(\boldsymbol{\%})$ \\
Paed & $12(8.4)$ & $14(12.2)$ & $19(10.9)$ & $45(10.4)$ \\
A/E & $46(32.2)$ & $36(31.3)$ & $53(30.5)$ & $135(31.3)$ \\
GOPD & $02(1.4)$ & $01(0.9)$ & $03(1.7)$ & $06(1.4)$ \\
Med & $15(10.5)$ & $4(3.5)$ & $14(8.0)$ & $33(7.6)$ \\
Surgery & $35(24.5)$ & $36(31.3)$ & $57(32.8)$ & $128(29.6)$ \\
Others & $22(15.4)$ & $19(16.5)$ & $21(12.1)$ & $62(14.4)$ \\
Private & $11(7.6)$ & $05(4.3)$ & $07(4.0)$ & $23(5.3)$ \\
Total & $143(100)$ & $115(100)$ & $174(100)$ & $432(100)$ \\
\hline
\end{tabular}


Table 3: Analysis of SARS-CoV 19 results in pediatric age group

\begin{tabular}{lllll}
\hline & & Males n = 145 & Females n = 139 & Total n = 284 \\
STATUS & Negative & $121(83.4)$ & $105(75.5)$ & F $(\%)$ \\
Total IgG & Positive & $24(16.6)$ & $34(24.5)$ & $226(79.6)$ \\
& Negative & $126(86.9)$ & $114(82.0)$ & $58(20.4)$ \\
Total Ig M & Positive & $19(13.1)$ & $25(18.0)$ & $240(84.5)$ \\
IgM/G & Negative & $128(88.3)$ & $118(84.9)$ & $44(15.5)$ \\
Isolated IgM & Positive & $17(11.7)$ & $21(15.1)$ & $246(86.6)$ \\
Isolated IgG & Negative & $121(83.4)$ & $105(75.5)$ & $226(79.6)$ \\
Combined IgM/G & Positive & $5(3.4)$ & $9(6.5)$ & $14(4.9)$ \\
\hline
\end{tabular}

Table 4: Analysis of SARS-CoV 19 results in adult age group

\begin{tabular}{lllll}
\hline & & Males $\mathbf{n}=\mathbf{6 5 3}$ & Females $\mathbf{n}=\mathbf{7 1 6}$ & Total $\mathbf{n}=\mathbf{1 3 6 9}$ \\
STATUS & F $(\boldsymbol{\%})$ & F $(\boldsymbol{\%})$ & F $(\boldsymbol{\%})$ \\
& Negative & $475(72.7)$ & $520(72.6)$ & $995(72.7)$ \\
Total IgG & Positive & $178(27.3)$ & $196(27.4)$ & $374(27.3)$ \\
& Negative & $531(81.3)$ & $592(82.7)$ & $1123(82.0)$ \\
Total IgM & Positive & $122(18.7)$ & $124(17.3)$ & $246(18.0)$ \\
IgM/G & Negative & $512(78.4)$ & $577(80.6)$ & $1089(79.5)$ \\
Isolated IgM & Positive & $141(21.6)$ & $139(19.4)$ & $280(20.5)$ \\
Isolated IgG & Negative & $475(72.7)$ & $520(72.6)$ & $995(72.7)$ \\
Combined IgM/G & Positive & $57(8.7)$ & $72(10.1)$ & $129(9.4)$ \\
\hline
\end{tabular}

\section{Discussion}

The mean age of the adult population in this study reflects the active age group reported with the highest sero-prevalence of SARSCov-2 ${ }^{[19]}$.

The highest number of requests were from the surgery and $\mathrm{A} / \mathrm{E}$ units, both accounted for more than half of the total requests received for the period of study. This suggests that these two units have very high patient load. They both yielded more than half of the positive results, which may be consequent on the patient load and the fact that $\mathrm{A} / \mathrm{E}$ remains the first point of care even for referrals.
Also, that referrals from other centers may be to $\mathrm{A} / \mathrm{E}$. This therefore, suggests that there may be a potential burden of SARSCoV-2 among patients presenting at these units and that a high index of suspicion would be required. Consequently, all patients attending the surgery unit should be screened as 1 in every 4 patients appeared to be exposed to SARSCoV-2. A similar pattern was found among the pediatric population in which 1 out of every 5 children screened was positive.

Requests were largely from patients seeking clinical care and these requests were sent as a prerequisite to medical consultation and not due to 
screening. The requests from outside facilities also showed the same reason which may reflect the fact that medical personnel were only taking necessary precautions as part of personal responsibility for their protection. Therefore, sending patients first for COVID 19 screening may be regarded as a precautionary measure to safeguard healthcare givers and protect other patients as well as the general facility ${ }^{[18]}$. The study revealed an overall SARSCoV-2 sero-prevalence of $26.4 \%$ with a higher $(27.3 \%)$ sero-prevalence in adults than children $(20.4 \%)$. The overall sero-prevalence and age pattern of sero-prevalence in this study is similar to reports by Majiya et al who reported a prevalence of $27.18 \%$ and $23.17 \%$ for males and females respectively with a higher prevalence in adults ${ }^{[19]}$.

The sero-prevalence of either IgG or IgM seropositivity appears the same irrespective of age or gender. However, the pattern of either a higher IgM or IgG sero-positivity appeared to be age dependent as children tend to have a higher IgG while there's a higher IgM in adults. It has been reported that IgM reactivity follows acute development of the immune response to the foreign agent compared to $\mathrm{IgG}$ which responds later and tends to follow a chronic pattern for a long term immunity ${ }^{[20]}$. This pattern is similar to higher IgM sero-positivity found in Italy among healthcare workers ${ }^{[21]}$. Sero-prevalence of Ig $\mathrm{M}$ and $\mathrm{IgG}$ in this study further buttress the fact that asymptomatic patients or those with subclinical infection among the patient population may serve as potential carriers of COVID-19 [21]. Thus, the pattern observed is that $\operatorname{IgG}$ or $\operatorname{IgM}$ alone may become readily positive and either of the two may be enough to suggest exposure to SARSCoV-2.

The slightly higher positive sero-prevalence found in females may be due to the relative higher proportion of female adult population. However, this appeared to be reversed among the pediatric group where there was a male preponderance. Nonetheless, females also had a higher positive sero-prevalence favoring the female gender was also noted in this group. This is contrary to a report from Niger State, Northcentral Nigeria where males had a higher sero-prevalence than females, although their sample size was small compared with that of this study ${ }^{[19]}$. Similarly, a higher prevalence of COVID-19 was found in males in Benin City,
South-south Nigeria [3]. This may be due to confirmatory PCR test done in those studies, which is a limitation in this study.

The higher sero-positivity of SARS-CoV 2 among females appeared to be age independent as both female adults and children in this study had a higher proportion of sero-positivity when compared with their male counterparts. In a study by Zeng et al among 331 confirmed patients with SARS-CoV 2 severe infection, Ig $\mathrm{G}$ level was found to be higher among females than males which may suggest that female patients generated a relatively higher levels of SARS-Cov $2 \mathrm{IgG}$ antibody and that $\mathrm{IgG}$ in females appeared to be stronger than that of males in the early phase of the infection ${ }^{[22]}$. Contrarily, higher sero-prevalence was reported for males in Niger State and Benin City which may be due to a male predominance in those studies ${ }^{[3,19,23]}$. In other studies on the relationship between gender and SARS-Cov 2 serology, no association was found ${ }^{\text {[24- }}$ ${ }^{25]}$. This may suggest that the female gender may be a risk factor for susceptibility to SARS-CoV-2 and that the older the female, the higher the risk. According to a study in North-central, Nigeria, female gender appears to be protective of COVID19 due to lower mobility and activity ${ }^{[19]}$ which characterize the environment of that study as against the more active and highly mobile nature of women in southern Nigeria. The probability that females have low immunity due to relatively low WBC count, may further explain the link between gender and COVID-19 infection. Therefore, gender may play a role in the immune response to COVID 19 infection either modulatory or modifying the susceptibility to the infection. This observation may suggest that for every male exposure there's twice the risk of infection in females. Based on the inconsistent findings on the role of gender in the development of SARSCoV-2 antibodies and the possibility of environmental influence, it may be difficult to justify this observation. Hence, further exploration studies are required to validate if truly, any relationship exists between COVID 19 infection and gender.

Limitation: the rapid diagnostic kit serology results could not be compared with results from PCR done in a separate facility with access restriction. 


\section{Conclusion}

In conclusion, the overall prevalence of SARSCoV-2 based on rapid serology test in a tertiary health facility is $26.4 \%$. The highest exposure was found among patients presenting at the surgery and $\mathrm{A} / \mathrm{E}$ departments thus, necessitating more precautionary measures by the hospital staff as every 1 in 4 patients are most likely infected with the SARSCoV-2. It is therefore recommended that the hospital management makes available resources that are crucial to implementing these measures. Also, guidelines and regulations should be formulated and enforced at all high-risk stations/units/departments.

\section{Conflicts of interests}

The authors declare no conflict of interest

\section{Authors' Contribution}

Ajeigbe A.K: conception, study design, data collection, data analysis, manuscript writing

Adedeji T.A: conception, study design and manuscript writing

Ajose O.A: study design, interpretation of data and manuscript writing writing

Jeje O.A: data collection and manuscript writing

Smith A.O: data collection and manuscript

Bello M.B: manuscript writing

Olukoyejo O.E: manuscript writing

Jokanola O.J: manuscript writing

Makinde R.A: data collection

Ojelabi I.H: data collection

Odun-Afolabi O.O: data collection

Ogra V.O: data collection

\section{References}

1 Zhu N, Zhang D, Wang W, Li X, Yang B, Song J, Zhao X, Huang B, Shi W, Lu R, Niu P, Zhan F, Ma X, Wang D, Xu W, Wu G, Gao GF, Tan W, China Novel Coronavirus I, Research T. A Novel Coronavirus from Patients with Pneumonia in China, 2019. N
Engl J Med 2020; 382(8): 727-733 DOI: 10.1056/NEJMoa2001017

2 WHO situation report. https://www.who.int/ docs/default-source/coronaviruse/situationreports/20200510covid-19-sitrep-111.pdf? sfvrsn=1896976f_2

3 Madubuike U.A, Ishmael J.F, Obichukwu C.N, Chinwe-Juliana I.J, James W.O. A Perspective on Nigeria's Preparedness, Response and Challenges to Mitigating the Spread of COVID-19. Challenges. 2020; 11(2): 1-15. [DOI:10.3390/challe11020022]

4 WHO.Consensus document on the epidemiology of severe acute respiratory syndrome (SARS). https://www.who.int/csr/WHOconsensus

5 Ihekweazu C, Agogo E. Africa's response to COVID-19. BMC Med 2020; 18(1): 151 DOI: 10.1186/s12916-020-01622-W

6 Nigeria Centre for Disease Control. An update of COVID-19 outbreak in Nigeria for week 27, 30 June, 2020

7 B.U Okwara, E.O Ogboghodo, I.I Osaigbovo, D.E Obaseki, C.E Omuemu, E. Eduware. An Analysis of COVID-19 Patients Receiving Care in a Tertiary Facility in Southern Nigeria. West Afr J of Medicine. 2020; 37(7):715-720

8 Docherty AB, Harrison EM, Green CA,Hardwick HE, Pius R, Norman L, Holden KA, Read JM, Dondelinger F, Carson G, Merson L, Lee J, Plotkin D, Sigfrid L, Halpin S, Jackson C, Gamble C, Horby PW, NguyenVan-Tam JS, Ho A, Russell CD, Dunning J, Openshaw PJ, Baillie JK, Semple MG, investigators IC. Features of 20133 UK patients in hospital with covid-19 using the ISARIC WHO Clinical Characterisation Protocol: prospective observational cohort study. BMJ 2020; 369: m1985 DOI: 10.1136/bmj.m1985

9 Dawood FS, Ricks P, Njie GJ, Daugherty M, Davis W, Fuller JA, Winstead A, McCarron M, Scott LC, Chen D, Blain AE, Moolenaar R, Li C, Popoola A, Jones C, Anantharam P, Olson N, Marston BJ, Bennett SD. Observations of the global epidemiology of COVID-19 from the prepandemic period using web-based surveillance: a cross-sectional analysis. Lancet Infect Dis 2020; 20(11): 
1255-1262 DOI: $\quad 10.1016 /$ S14733099(20)30581-8

10 Lai CC, Liu YH, Wang CY, Wang YH, Hsueh SC, Yen MY, Ko WC, Hsueh PR. Asymptomatic carrier state, acute respiratory disease, and pneumonia due to severe acute respiratory syndrome coronavirus 2 (SARSCoV-2): Facts and myths. $J$ Microbiol Immunol Infect 2020; 53(3): 404-412 DOI: 10.1016/j.jmii.2020.02.012

11 Bowale A, Abayomi A, Idris J, Omilabu S, Abdus-Salam I, Adebayo B, Opawoye F, Finnih-Awokoya O, Zamba E, Abdur-Razzaq $\mathrm{H}$, Erinoso O, Onasanya T, Ramadan $\mathrm{P}$, Nyenyi S, Aniaku E, Balogun M, Okunromade $\mathrm{O}$, Adejumo $\mathrm{O}$, Adesola $\mathrm{S}$, Ogunniyan $\mathrm{T}$, Balogun M, Osibogun A. Clinical presentation, case management and outcomes for the first 32 COVID-19 patients in Nigeria. Pan Afr Med J 2020; 35(Suppl 2): $24 \quad$ DOI: 10.11604/pamj.supp.2020.35.2.23262

12 Dong Y, Mo X, Hu Y, Qi X, Jiang F, Jiang Z, Tong S. Epidemiology of COVID-19 Among Children in China. Pediatrics 2020; 145(6) DOI: $10.1542 /$ peds. 2020-0702

13 Zhou F, Yu T, Du R, Fan G, Liu Y, Liu Z, Xiang J, Wang Y, Song B, Gu X, Guan L, Wei Y, Li H, Wu X, Xu J, Tu S, Zhang Y, Chen H, Cao B. Clinical course and risk factors for mortality of adult inpatients with COVID-19 in Wuhan, China: a retrospective cohort study. Lancet 2020; 395(10229): 1054-1062 DOI: 10.1016/S0140-6736(20)30566-3

14 Oluwadare Ogunlade.The Development of Ogunlade COVID-19 Diagnostic Criteria (OCDC) and OCRAS for Management of Coronavirus Disease 2019 (COVID-19) Pandemic. 2020. American Journal of Biomedical Sciences. 2020; 12(3):183-190. [DOI: 10.5099/aj200300183]

15 Lippi G, Simundic AM, Plebani M. Potential preanalytical and analytical vulnerabilities in the laboratory diagnosis of coronavirus disease 2019 (COVID-19). Clin Chem Lab Med 2020; 58(7): 1070-1076 DOI: $10.1515 / \mathrm{cclm}-2020-$ $\underline{0285}$

16 Corman VM, Landt O, Kaiser M, Molenkamp R, Meijer A, Chu DK, Bleicker T, Brunink S, Schneider J, Schmidt ML, Mulders DG,
Haagmans BL, van der Veer B, van den Brink S, Wijsman L, Goderski G, Romette JL, Ellis J, Zambon M, Peiris M, Goossens H, Reusken C, Koopmans MP, Drosten C. Detection of 2019 novel coronavirus (2019-nCoV) by realtime RT-PCR. Euro Surveill 2020; 25(3) DOI: $10.2807 / 1560-$

7917.ES.2020.25.3.2000045

17 Li Z, Yi Y, Luo X, Xiong N, Liu Y, Li S, Sun R, Wang Y, Hu B, Chen W, Zhang Y, Wang J, Huang $\mathrm{B}$, Lin $\mathrm{Y}$, Yang J, Cai W, Wang $\mathrm{X}$, Cheng J, Chen Z, Sun K, Pan W, Zhan Z, Chen L, Ye F. Development and clinical application of a rapid IgM-IgG combined antibody test for SARS-CoV-2 infection diagnosis. J Med Virol 2020; $92(9)$ : 1518-1524 DOI: 10.1002/jmv.25727

18 Oluwafemi I, Ayuba S.B, Tanko Z.L, Tahir M, Livingstone D, Ijei I.P, Bello-Manga H, Audu R, Ige S, Nmadu G. Evaluation of SARS-CoV2 antibody Rapid Diagnostic Test kits (RDTs) and Real Time-Polymerase Chain Reaction (Rt-PCR) for COVID-19 diagnosis in Kaduna, Nigeria. 2020. Med Rxiv. [DOI: 10.1101/2020.11.24.20231324]

19 Majiya H, Aliyu-Paiko M, Balogu V.T., Musa D.A., Salihu I.M., Kawu A.A, Bashir Y.I, Sani R.A, Muhammad J.B, Jibril A.T, Bala F.L, Obaje N.G, Aliyu B.Y, Muhammead R.G, Muhammed H, Gimba N.U, Utman A, Liman H.M, Sule A.A, Joseph K.J, Makusudi M.M, IsahM.D, Abdullahi I, Ndagi U, Waziri B, BisallahC.I, Dadi-Mamud N.J, Ibrahim K, Adamu A.K. Sero-prevalence of COVID-19 in Niger State. Med Rxiv. 2020; 5:1-22. [DOI: 10.1101/2020.08.04.20168112]

20 Su S, Wong G, Shi W, Liu J, Lai ACK, Zhou J, Liu W, Bi Y, Gao GF. Epidemiology, Genetic Recombination, and Pathogenesis of Coronaviruses. Trends Microbiol 2016; 24(6): 490-502 DOI: 10.1016/j.tim.2016.03.003

21 Sotgiu G, Barassi A, Miozzo M, Saderi L, Piana A, Orfeo N, Colosio C, Felisati G, Davi M, Gerli AG, Centanni S. SARS-CoV-2 specific serological pattern in healthcare workers of an Italian COVID-19 forefront hospital. BMC Pulm Med 2020; 20(1): 203 DOI: $10.1186 / \mathrm{s} 12890-020-01237-0$ 
Zeng F, Chen X, Deng G. Convalescent plasma for patients with COVID-19. Proc Natl Acad Sci USA 2020; 117(23): 12528 DOI: 10.1073/pnas.2006961117

23 Madubuike U.A, Ishmael J.F, Obichukwu C.N, Chinwe-Juliana I.J, James W.O. A Perspective on Nigeria's Preparedness, Response and Challenges to Mitigating the Spread of COVID-19. Challenges. MDPI AG; 2020 Sep 21;11(2):22. DOI: $10.3390 /$ challe11020022

24 Garcia-Basteiro AL, Moncunill G, Tortajada M, Vidal M, Guinovart C, Jimenez A, Santano R, Sanz S, Mendez S, Llupia A, Aguilar R, Alonso S, Barrios D, Carolis C, Cistero P, Choliz E, Cruz A, Fochs S, Jairoce C, Hecht J, Lamoglia M, Martinez MJ, Mitchell RA, Ortega N, Pey N, Puyol L, Ribes M, Rosell N, Sotomayor P, Torres S, Williams S, Barroso S, Vilella A, Munoz J, Trilla A, Varela P, Mayor A, Dobano C. Seroprevalence of antibodies against SARS-CoV-2 among health care workers in a large Spanish reference hospital.

Nat Commun 2020; 11(1): 3500 DOI: 10.1038/s41467-020-17318-X

25 Havers FP, Reed C, Lim T, Montgomery JM, Klena JD, Hall AJ, Fry AM, Cannon DL, Chiang CF, Gibbons A, Krapiunaya I, Morales-Betoulle M, Roguski K, Rasheed MAU, Freeman B, Lester S, Mills L, Carroll DS, Owen SM, Johnson JA, Semenova V, Blackmore C, Blog D, Chai SJ, Dunn A, Hand J, Jain S, Lindquist S, Lynfield R, Pritchard S, Sokol T, Sosa L, Turabelidze G, Watkins SM, Wiesman J, Williams RW, Yendell S, Schiffer J, Thornburg NJ. Seroprevalence of Antibodies to SARS-CoV-2 in 10 Sites in the United States, March 23-May 12, 2020. JAMA Intern Med 2020 DOI: 10.1001/jamainternmed.2020. $\underline{4130}$ 